\title{
Fish Farming Development Potency with Floating Fish Cage System in Amurang District, South Minahasa Regency, Indonesia
}

\author{
Eva Maryani Rita Mukuan ${ }^{1,}$ Sukoso ${ }^{2}$,Diana Arfiati ${ }^{3}$, Rene Ch.Kepel ${ }^{4}$, \\ ${ }^{1}$ Environmental Sciences and Technology Graduate Program, University of Brawijaya Malang, Indonesia \\ Jl.M.T.Haryono No.169 Malang, Jawa Timur, Indonesia \\ Natural Resources Division of Regional Secretariate, North Sulawesi Province. Jl.17 Agustus Manado, \\ Indonesia \\ ${ }^{2,3}$ Faculty of Fisheries and Marine Science, Brawijaya University, MalangJl.Veteran Malang 65145 Jawa \\ Timur, Indonesia \\ ${ }^{4}$ Faculty of Fisheries and Marine Science, Sam Ratulangi University, ManadoJl. Kampus Unsrat,Bahu, \\ Manado, Indonesia
}

\begin{abstract}
Coastal waters of South Minahasa Regency is potential for fish farming of floating fish cage system, but the potency has not been optimally taken yet.Low interest of the people in running this fish farming system results from slow fish growth and mortality.In general, the failure of this culture system is a consequence of location setting that does not consider the water quality condition as a site suitability requirement. Until now, there is no study on site suitability of fish farming in floating nets in South Minahasa Regency, particularly Amurang District, affecting the fish farming success.This study was aimed at determining the site suitability for trevally (caranx spp.) farming using the floating fish cage system in the coastal waters of Amurang District, South Minahasa Regency. It was carried out in Amurang Bay using a survey method. The primary data was obtained by direct field measurement at the observation points using a Global Positioning System (GPS). The determination of sampling points was expected to be able to describe the condition of Amurang waters. The secondary datacovered the 1:50.000-scaled earth map of South Minahasa with Arc-Info format released from Badan Koordinasi Survei and Pemetaan Nasional (Bakorsutanal-National Coordination Body for Survey and Mapping) and Landsat 7-ETM image. Water samples were analyzed in the Water Laboratory Nusantara. Data Analyisesused Geographic Information System..In general, sites for floating cage fish farming in Amurang District were categorized as suitable, conditional suitable, unsuitable.The area available and potential for this culture system was 150 Haandsuitable for trevally (caranx spp.) culture was38 Ha. This suitability data was expected to become critical information and reference for the regional government, investors, fishermen and fish farmers in developing the fish culture in the floating fish cage.
\end{abstract}

Keywords: site feasibility, suitability, water quality.

\section{Introduction}

Mariculture development is an effort to utilize the potency of coastal area and sea space in raising the fisheries production in order to increase the public welfare through environmental preservation. It is supported by large coastal and marine areaswith highly suitable water conditions. According to Majariana et al. (2006)[1] and FAO (2010)[2], the continuity of fish culture with floating fish cage system is highly dependent upon the carrying capacity of environment, and all aquaculture activities should be environmental friendly so that the fish culture could be sustained.

Suitable site selection is one of the factors determining the mariculture success beside the availability of fry, feed and market assurance. According to Milne (1979)[3], Muir and Kapetsky (1998)[4], Purnomo (1992)[5], Sukandi (2002)[6], and Mustafa et al. (2011)[7], correct site selection is a critical factor in determining the feasibility of fish culture business. Site selection is absolutely important for the fish culture success as well. The appropriate site selection is one of the initial steps necessary to do in order to avoid serious negative impact on the surrounding environment. It should account for environmental factors, such as water quality, since it is an important part of the fish culture.Good water needs oxygen, the proper $\mathrm{pH}$ and chemical balance, and the correct water temperature for the type of fish you want to raise. The better the water quality, the more fish you will harvest for your efforts (Fuller dan Holly, 2010) [8].

South Minahasa Regency is one of the regencies in North Sulawesi Province that possesses a coastal area with $168.22 \mathrm{~km}$ long coastalline facing Sulawesi Sea with an area of 56,000 Ha (4 miles)and mariculture potency of 3,570Haconsisting of seaweeds $2,510 \mathrm{Ha}$, fish culture of floating net system 1,050 $\mathrm{Ha}$ and seacucumber culture $10 \mathrm{Ha}$ (Anonymous,2011)[9]. 
One of maricultures potential to develop in the coastal waters of South Minahasa Regency is the fish farming with floating fish cage for grooper and trevally.The floating fish cage system for trevally culture is the commodity mostly preferred in Amurang District. Nevertheless, this culture activities have not been well developed relative to the available potency. Fish culture potency in the coastal waters of South Minahasa Regency is relatively large, but its utilization is still low. It results from low people interest to do the floating cage system-fish culture activity as a result of many failures in fish culture of this system. These result from slow fish growth and high mortality rate. Failures in fish culture are also brought about by site selection without taking into account of water quality conditions as site suitability requirements.Until now, there is no study on fish culture suitability location for fish farming with floating net system in South Minahasa Regency, especially Amurang District, so that the floating net facilities setting has not considered the site feasibility resulting in failures in this fish culture system.Detail analysis of areal specification for mariculture was done so far without starting with study on site suitability, carrying capacity and site status highly affecting the success and the continuity of the fish culture activities(Nontji, 2005)[10].In fact, site determination for culture development has been conducted on trial and errorbasis (Hartoko and Helmi, 2004)[11].

This study was aimed at knowing the site feasibility for fish farming with floating net system based on water quality parameters requisited and assessing the site suitability of fish farming with floating net system in Amurang waters. This result will provide information on the characteristic and the suitability of the waters for floating net fish culture so that locations and coastal water coverage viable for floating net system-based fish culture development in Amurang District, South Minahasa Regency, North Sulawesi Province, could be determined.

\section{Method Research}

The study used a survey method. Data consisted of primary and secondary one. The former was obtained by direct field measurement at the observation points using a Global Positioning System (GPS). The latter covered the 1:50.000-scaled earth map of South Minahasa-NLP 2417-12 with Arc-Info format released from Badan Koordinasi Survei dan Pemetaan Nasional (Bakorsutanal-National Coordination Body for Survey and Mapping) and Landsat 7-ETM Digital image. Sampling points were set as many as 40 points distributed from Ranoyapo to Bitung waters.Data analyses used Geographic Information System. These were analyzed using geaostatistics, by interpolating dot data into area (polygon) using thenearestneighbour method(Prahasta, 2002)[12] and constructed into thematic maps. The classification of areal suitability level was done by creating a suitability matrix to assess the feasibility based on scoring the limiting parameters of the floating net fish culture activities. The culture limiting parameter suitability class was determined based on the response of the cultured fish growth, and each parameter was divided into four classes, highly suitable, suitable, conditionally suitable, and unsuitable.Those classes were successively scored from the highest to the lowest as 4, 3, 2 and1. Moreover, each of the parameters was valued based on literatures for use in the assessment or the determination of areal suitability. The parameter that could give stronger effect will be given higher score than the weaker.Total score of the multiplication of parameter and score values was then used to determine the suitability class of the culture area for floating net fish farming based on the characteristics of water quality as follows:

$$
\begin{aligned}
& \mathrm{Y}=\sum \text { ai. } \mathrm{Xn}, \text { where: } \\
& \mathrm{Y}=\text { final value } \\
& \text { ai }=\text { valueing factor } \\
& \mathrm{Xn}=\text { value of areal suitability level }
\end{aligned}
$$

The class interval of the areal suitability was obtained using theEqualInterval method (Prahasta, 2002)[12] to divide the coverage of the attribute values into sub-coverages of similar size.The calculation was as follows:

$$
\mathrm{I}=\frac{\left(\sum \mathrm{ai} . \mathrm{Xn}\right)-\left(\sum \mathrm{ai} . \mathrm{Xn}\right)}{\mathrm{k}}
$$

Where I = class Interval of the area suitability, $\mathrm{k}=$ number of preferred area suitability classes. Based on the formula above, the class intervals and the area suitability scores were obtained. The water parameter suitability for marine fish culture in the floating net was categorized highly suitable, sufficiently suitable, conditionally suitable and unsuitable. Determination of culture method suitable for the floating net fish culture was carried out using matching method between the suitability classes set in fish culture method criteria of floating fish cage system.

To obtain the floating net culture potency breadth, all potential areas were calculated using GIS andto gain the extent value of the floating net fish culture in the study site, it was obtained based on the calculation and the data input of each parameter possessing the value and the score of the floating net culture suitability criteria.

\section{Results And Discussion}




\section{General Conditions of Amurang District Waters}

Amurang District is one of the districts in South Minahasa Regency comprising 8 villages with the following boundaries: the north with Sulawesi Sea, the south withSoutheast Minahasa Regency, the east with East Amurang district, and the west with west Amurang district.There are 3 villages along the coastal line, Ranoyapo with $2 \mathrm{~km}$ long coastal line, Bitung with $2 \mathrm{~km}$ long coastal line, and Uwuran Satu with $1 \mathrm{~km}$ long coastal line. Ranoyapo and Bitung werevillages whose coastal waters was used for trevally, Caranx sp., culture in the floating net.

The coastal waters of South Minahasa Regency is largely affected by Pacific Ocean water mass passing the eastern Indonesia waters to Indian Ocean (arus lintas Indonesia-Arlido). In June to August, Arlindo reaches its peak at the Southeast Monsoon and called as South Season. Locally, water currents along the South Minahasa peninsular are largely influenced by the coastal topographic characteristics and tides in which tidal currents determinethe direction and the the speed of local current.In February, the current along the South Minahasa peninsular generally moved southwards at high tide and northwards at low tide with a velocity of 10$30 \mathrm{~cm} / \mathrm{sec}$.(Anonymous, 2011)[9]. Tide in this area is affected by the water mass of North Pacific. This water mass partly enters Sulawesi Sea and partly goes to Mallucas Sea. The water mass propagation as tidal currents results in a semi diurnal mixed tide type or two high tides and two low tides a day with different amplitude.

\section{Water Quality and Location Feasibility of Amurang District Waters}

The characteristics of Amurang district waters, based on water quality parameter measurements at 40sampling points in Ranoyapo to Bitung are as follows:

\section{Water Temperature}

Water temperature plays an important role for marine life and biota development in which increase in water temperature can reduce the dissolved oxygen content affecting matebolism rate, such as respiration and oxygen consumption and raise the carbon dioxide concentration. Changes in water temperature will influence the water suitability level as aquatic organism habitat, and therefore every aquatic organism has temperature range limits (Efendi, 2003)[13]. Water temperatures at study sites were $\pm 30.9^{\circ} \mathrm{Cand} \pm 30.55^{\circ} \mathrm{C}$ for Ranoyapo and Bitung, respectively. According to Mayunar et al.(1995)[14], optimum temperature for fish culture ranges from 27 to $32^{\circ} \mathrm{C}$, and thus water temperature in Amurang District is in the rangesuitable for floating net fish farming.

\section{Visibility}

Visibility is a condition indicating light ability to penetrate the water layer up to certain depth. The visibility in Ranoyapo ranged from 1.1 to $4 \mathrm{M}$ deep and in Bitung from 1.55 to $4 \mathrm{M}$ deep, respectively. The differenrce in water visibility is related with location water depth and observation time. Water visibility allowed for fish culture ranged from 5-10 M deep (Bakosurtanal, 1996[15] ; Wibisono, 2005 [16] ). Our findings indicated that water visibility at the study site was categorized as sufficiently suitable and conditionally suitable. According to Wibisono (2005)[16], water visibility is dependent upon bottom relief.

\section{Water depth}

Water depth is very important for fish culture installation establishment. It ranged from10-35 M deep in Ranoyapo and 10-45 M deep in Bitung, respectively. The water depth in this study ranged from unsuitable, conditionally suitable, suitable and highly suitablefor floating fish cage culture system. According to Beveridge (1996)[17],the ideal depth this fish culture system ranged from 6-25 M deep. The shallower the water is, the higher the tidal influence. The tide-affected areas have high turbidity level.According to Odum (1979)[18], shallow water possesses relatively higher current speed than deeper water.

\section{Bottom substrates}

Bottom substrates are important to maintain the sediment stability including protection from water currents and nutrient processing and entering site (Dahuri,2003[19]). These exhibited that Ranoyapo waters possesses muddy bottom and sandy muddy bottom, while Bitung has sandy bottom. Bottom substrates of Ranoyapo were partly categorized as unsuitable for fish culture, and the other as conditionally suitable for fish culturein floating fish cage system while Bitung is still in the range reccomended for mariculture. Suitable bottom substrate for fish culture is sandy bottom (Bakosurtanal, 1996 [15]; Radiarta et al, 2003) [20].

\section{Wave height}

The wave height measured in Amurang waters in March2012 ranged from $0.058-0.098 \mathrm{M}$ in Ranoyapoand from $0.077-0.090 \mathrm{M}$ in Bitung waters, respectively. For fish culture, it is lower than $0.5 \mathrm{M}$ deep 
(Balitbang SDL P3OLIPI, 1995) so that the wave will not damage the culture facility construction. The wave height inAmurang district was categorized as suitable for fish culture activities.

\section{Currents}

Currents take important role in water circulation. Beside as dissolved material transporter, current also affects number of oxygen solubilities in the water. In floating fish cage culture system, current strength can reduce fouling organisms living on the net so that the cage design and construction should be conditionally set with current speed and sea bottom characteristic (mud, sand, and coral). Mayunar et al.(1995)[14]found that epi- and periphytons will be more attached to the net if the current speed is below $25 \mathrm{~cm} / \mathrm{sec}$. and will reduce water circulation and dissolved oxygen. Current speed measurement of the study site inAmurang district ranged from $25-33 \mathrm{~cm} / \mathrm{sec}$. in Ranoyapo and $25-32 \mathrm{~cm} / \mathrm{sec}$. in Bitung waters, respectively. Average current speed in Amurang district was still in suitable range for floating fish cage culture system.

\section{Dissolved oxygen}

Dissolved oxygen in the water is an important factor as metabolic regulator of the organism to grow and multiply. Dissolved oxygen comes from oxygen diffusion in the atmosphere, current or water flow throughrainfalls and photosynthetic activities by aquatic plants, and phytoplankton (Novotny,1994[21]; Manik, 2003[22]). Dissolved oxygen is used as pollution level indicator. High dissolved oxygen indicates relatively low pollution level (Sugiharto 1987[23]). Polluted water has low dissolved oxygen. It results from that dissolved oxygen in the water is utilized by bacteria to break down the pollutant. If dissolved oxygen available in the water is very low, it will affect the the growth rate of aquatic organisms. Dissolved oxygen concentration in this study ranged from $5.5-9.9 \mathrm{mg} / \mathrm{l}$ in Ranoyapo with an average of $7.45 \mathrm{mg} / \mathrm{l}$ and $5.6-13.3 \mathrm{mg} / \mathrm{lin}$ Bitung with an average of $10.06 \mathrm{mg} / \mathrm{l}$. These values, according to North Sulawesi Governor's decree numbered 99, 2003 and Environmental Minister's decree numbered 51, 2004 concerning seawater quality standard (KMNLH, 2004[24]), are very suitable for floating fish cage culture since the mean dissolved oxygen is above $7 \mathrm{mg} / \mathrm{l}$, except that the area near the river mouth is categorized as suitable enough with DO of $5.5-6.8 \mathrm{mg} / \mathrm{l}$.This follows Lee at al. (2001)[25]that the lowest DO concentration potential for the floating fish cage culture suitability is $4 \mathrm{mg} / \mathrm{l}$. According toMayunar et al. (1995)[14], to survive fish need $1 \mathrm{mg} / \mathrm{l} \mathrm{DO}$, but to grow and develop they need a minimum concentration of $3 \mathrm{mg} / \mathrm{l}$. For fish culture, the optimum DO ranges from $5-8 \mathrm{mg} / \mathrm{l}$ (Ahmad et al., 1991)[26].

\section{Ammonia (NH3)}

Ammonia (NH3) can originate from maricultural wastes, such as feces and uneaten feed, released into the water (Barg, 1992)[27]. Fish cannot tolerate the high free ammonia level since it could disturb the oxygen binding process by the blood and could also gradually cause suffocation or mortality from limpness (Effendi, 2003)[13]. Average ammonia (NH3) content at the study sites was $0.03 \mathrm{mg} / \mathrm{l}$ in Ranoyapo and $0.02 \mathrm{mg} / \mathrm{l}$ in Bitung waters, respectively. These values were still below the water quality standard thresholds according to North Sulawesi Governor's decree numbered 99, 2003 andEnvironmental Minister's decree numbered 51, 2004, as much as $0.3 \mathrm{ppm}$ for marine biota.

\section{Salinity}

Salinity is salt content measurement of seawater with a one-thousandth unit (o/oo). Seawater salinity itself has a range of 30-36 ppt (Brotowidjoyo,et al.,1995)[28]. All aquatic organisms can live in the water of small salinity changes (Hutabarat and Evans, 1995)[29].Variation in salinity in the open sea will be relatively lower than that in the coastal waters, particularly where there is a river mouth.Water salinity in Ranoyapo ranged from $16 \mathrm{ppt}$ to $29 \mathrm{ppt}$ and in Bitung from $22 \mathrm{ppt}$ to $31 \mathrm{ppt}$, respectively. In general, average value of water salinity in Amurang district still reflected good range for fish culture activities of floating cage system, but the location near the river mouth had less suitable salinity for fish culture. Water salinity changes indirectly affect the fish behavior or distribution, but the seawater chemicalfeatures (Brotowidjoyo et al, 1995)[28]. The salinity suitable for fish ranges from 20 to 34 ppm (Imanto et al., 1995)[30].

BOD5

BOD5 is one of the organic water pollution indicators. High water BOD5 indicates that the water is contaminated by organic matters. Ranoyapo waters had BOD5 values of $2-4 \mathrm{ppm}$ with an average of $2.85 \mathrm{ppm}$ and Bitung waters had BOD5 of $2-4 \mathrm{ppm}$ with an average of $2.65 \mathrm{ppm}$. These values were below the threshold of water qulity standard of North Sulawesi Governor's decree numbered 99, 2003 and Environmental Minister's decree numbered 51, 2004,for marine biota, $<12 \mathrm{ppm}$. 


\section{Nitrate}

Nitrate can reduce the dissolved oxygen, fish population, and make the water get rotten quickly and smell bad.Nitrate concentration suitable for cultured organisms ranges from $0.2525-0.6645 \mathrm{mg} / \mathrm{l}$ (Winanto, 2004)[31]. Nitrate concents were averagely $0.062 \mathrm{mg} / \mathrm{l}$ in Ranoyapo waters and0.096 mg/l in Bitung waters, in which those concentrations were feasible for fish culture of floating cage system.

\section{Water Acidity (pH)}

Fish survival and growth are largely affected by water acidity $(\mathrm{pH})$. Theseawater $\mathrm{pH}$ ranges from $7.5-$ 8.4, and gets lower toward the coast due to freshwater inputs. Acid water tends to result in fish mortality since low dissolved oxygen causes high respiration rates and low feeding (Ghufron and Kordi, 2005)[32]. Water $\mathrm{pH}$ is usually influenced by photosynthesis rate, industrial and household disposals (Sastrawijaya, 2000)[33]. The pH value of Amurang district waters ranged from 8.15-8.33 in Ranoyapo and $8.15-8.25$ in Bitung, respectively. These ranges are categorized as suitable for fish cuture since marine fishes can generally thrive at the $\mathrm{pH}$ above 7(Radiarta et al.,2006)[20].

\section{Phospate}

Phospate concentration in the study site ranged from 0.004 to $0.005 \mathrm{mg} / \mathrm{l}$ in Ranoyapo and $0.005 \mathrm{mg} / \mathrm{lin}$ Bitung waters, respectively. This condition indicates that phosphates at the study site meet the requirement for fish culture of floating cage system.According to Anonymous (1985)[34],phosphate concentration for fish culture ranged from $0.0062 \mathrm{mg} / \mathrm{l}-0.093 \mathrm{mg} / \mathrm{l}$. Higher concentration than the tolerance limit could inhibit the fish growth.

\section{Plankton}

Laboratory studies showed that only phytoplankton were found in Bitung waters and both phytoplankton and zooplankton in Ranoyapo waters (Table 1).Plankton is floating microorganism that moves following the water current ( $\mathrm{Bal}$ and Rao, 1984)[35]. They have important role inmarine ecosystem due to becoming food materials for various marine life (Nontji, 1993[36] ;Nybakken, 1992[37]).

Table 1 Plankton Distribution

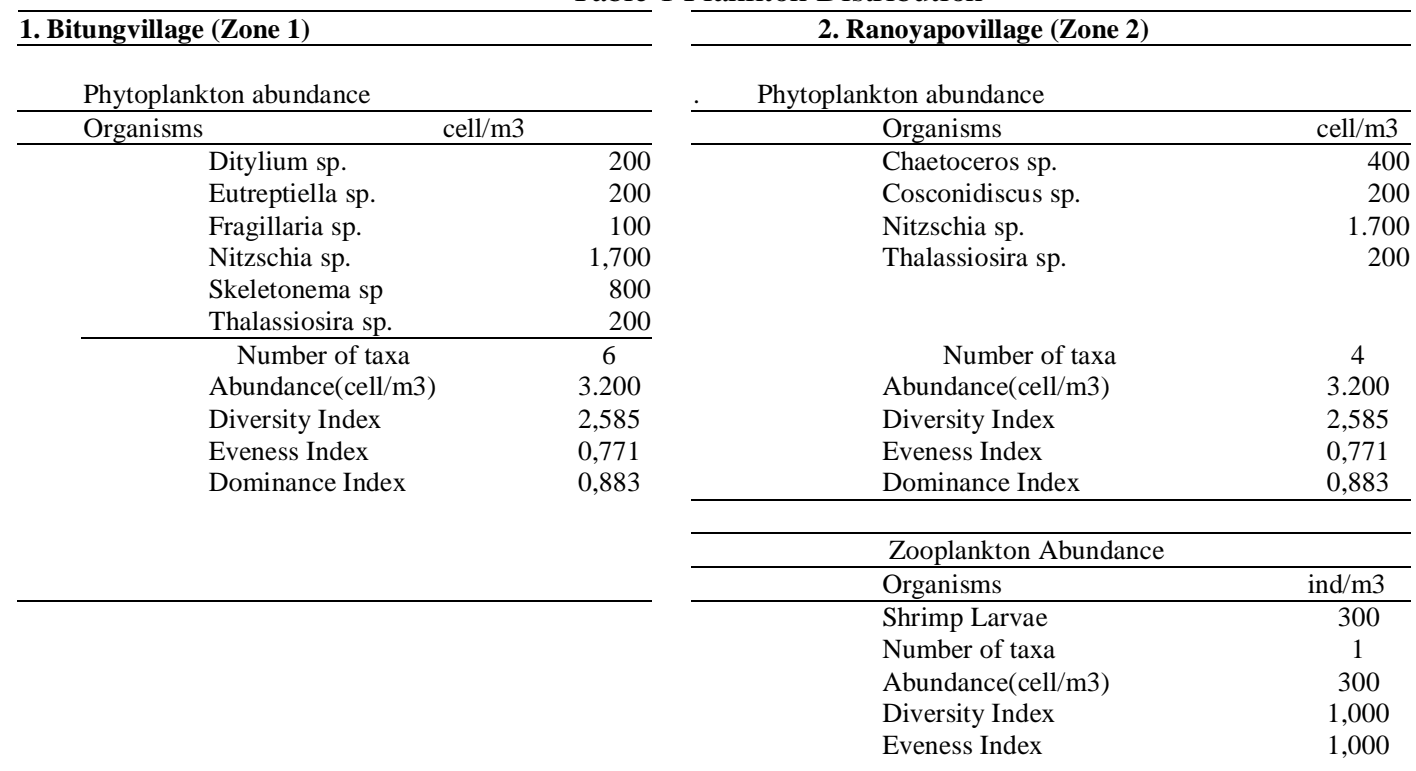

\section{Location Suitability for Floating Net Fish Culture}

Water quality parameters of Amurang district, South Minahasa regency, were abalyzed using GIS software and then overlaid to obtain the figure of water quality suitability for fish culture of floating fish cage system (Figure 1). Site suitability valuation in Amurang waters reflected that potential area for trevally culture in floating fish cage was $150 \mathrm{Ha}$ and suitable for fish culture under this system was $38 \mathrm{Ha}$.

In general, site suitability for trevally culture in the floating fish cage in Amurang district is categorized as suitable, conditionally suitable, and unsuitable.One of the limiting factors of the unsuitability is the position of Ranoyapo close to the river mouth which causes the bottom substrates become muddy and sandy muddy. 

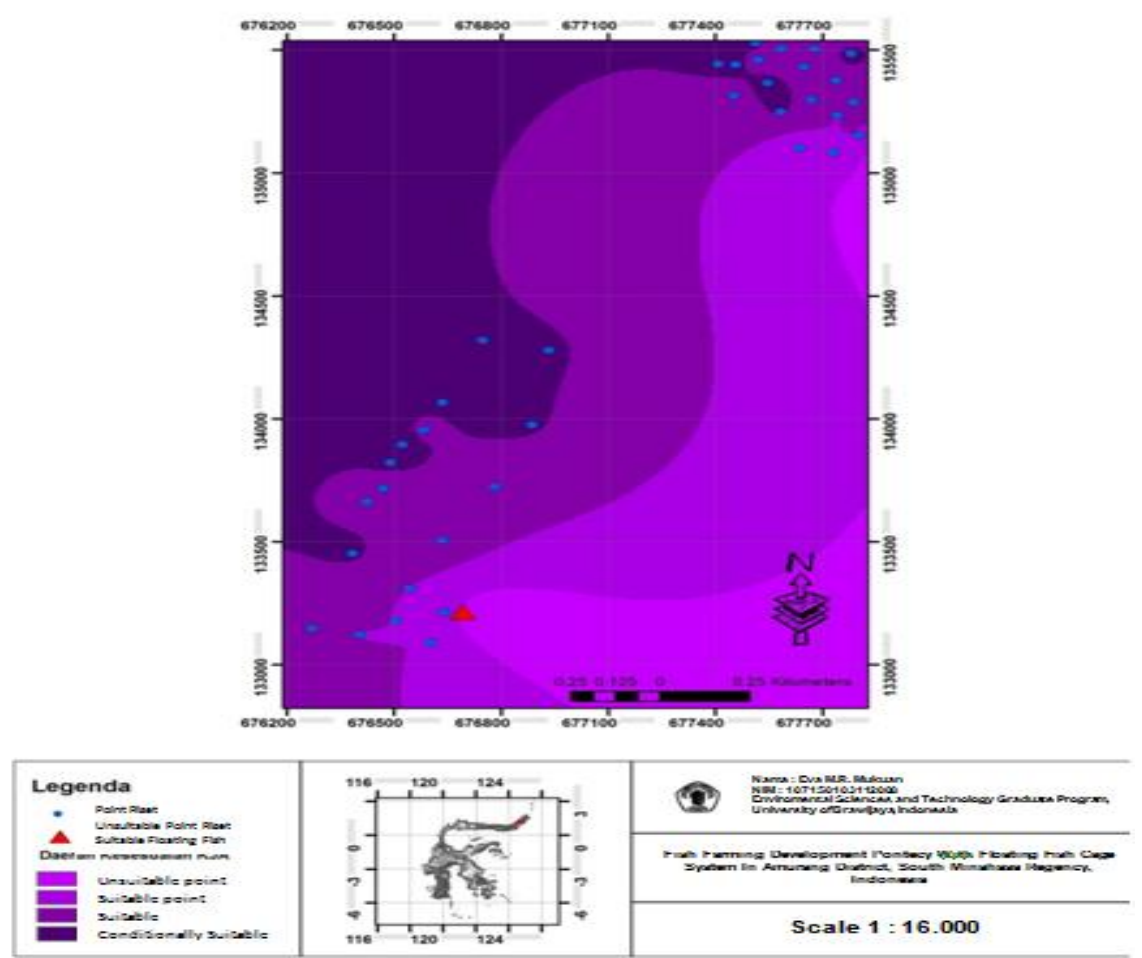

Figure 1 Suitability map of fish farming in the floating fish cage Source: Data processing output

\section{Conclusion}

Based on the oceanographic measurements, Amurang waters feasible to establish trevally fish culture site with floating fish cage system covered $38 \mathrm{Ha}$, where the culture potency for floating fish cage was $150 \mathrm{Ha}$. Nevertheless, the areal suitabilities were cagegorized as suitable, conditionally suitable, and unsuitable.

\section{Recommendation}

Setting the Floating Fish Cage system in trevallyculture in Amurang District is expected to consider the site suitability based on physical, oceanographic and biological conditions supporting the fish culture system so that the success could be gathered and sustained. Field observations suggested that trevally culture development should better be done in Bitung, since Bitung waters has more suitable bottom substrate.

\section{Journal Papers}

\section{References}

[1] Majariana,K dan Zulhamsyah,I. 2006. Daya Dukung Lingkungan Perairan Teluk Ekas Untuk Pengembangan Kegiatan Budidaya Ikan Kerapu Dalam Karamba Jaring Apung. Jurnal Ilmu Pertanian Indonesia, Institut Pertanian Bogor, Bogor. J.II.Pert.Indon. Vol.II (2). 2006

[6] Sukandi, M. F. 2002.Peningkatan Teknologi Perikanan ( The Improvement ofFish Culture Technology). Journal Icthyoligi Indonesia.Vol 2 No 2. Hal 61-66 University Press. Oreginal English Edition. Fundamental of EcologyThurd Edition, Yokyakarta

[8] Fuller, Holly.2010.m Publication info: Countryside and Small Stock Journal 94.2 (Mar/Apr 2010): 35-36. ProQuest document link

[11] Hartoko,A dan Helmi,M. 2004. Development of Digital Multilayer Ecological Model for Padang Coastal Water (West Sumatera). Journal of Coastal Development. Vol 7.No 3 hal 129-136.

[20] Radiarta, I. Ny., A. Saputra., O, Johan. 2005. Pemetaan Kelayakan Lahan untuk Pengembangan Usaha Budidaya Laut dengan Aplikasi Inderaja dan Sistem Informasi Geografis di Perairan Lemito, Propinsi Gorontalo. Jurnal Penelitian Perikanan Indonesia, Vol.11 No 1 hal 1-13.

Books:

[3] Milne, P. H. 1979. Fish and Shellfish Farming in Coastal Waters.Fishing NewsBook Ltd, Farnham Surrey

[9] Anonimous.2011. Profil Kabupaten Minahasa Selatan.Dinas Kelautan dan Perikanan Kabupaten Minahasa Selatan.

[10] Nontji, A. 2005. Laut Nusantara. Edisi revisi. Penerbit Djambatan, Jakarta.

[12] Prahasta, E. 2002.Konsep-Konsep Dasar Sistem Informasi Geografis. Penerbit Informatika, Bandung.

[13] Effendi. H. 2003. Telaah Kualitas Air bagi Pengelolaan Sumberdaya dan Lingkungan Perairan. Penerbit Kanisius, Yogyakarta

[15] Bakosurtanal.1996. Pengembangan Prototipe Wilayah Pesisir dan Marin Kupang-Nusa Tenggara Timur. Pusat Bina Aplikasi Inderaja dan Sistem Informasi Geografis, Cibinong

[16] Wibisono, M. S. 2005. Pengantar Ilmu Kalautan. Penerbit PT. Gramedia Widiasarana Indonesia, Jakarta

[17] Beveridge,M.C.M.1996. Cage Aquaculture (Second Edition), Fishery Brok LTD. Farnhan, Surrey, England. 352pp

[18] Odum, E. P. 1979. Dasar-Dasar Ekologi. Edisi Ketiga. Gadjah Mada

[19] Dahuri, R. 2003. Keanekaragaman Hayati Laut; Aset PembangunanBerkelanjutan. Penerbit PT. Gramedia Pustaka Utama, Jakarta. 
[22] Manik.KES.2003. Pengelolaan Lingkungan Hidup. Djambatan. Jakarta.

[23] Sugiharto.1987. Dasar-Dasar Pengelolaan Air Limbah-UI-Press

[28] Brotowijoyo, M. D., Dj. Tribawono., E. Mulbyantoro. 1995. Pengantar Lingkungan Perairan dan Budidaya Air. Penerbit Liberty, Yogyakarta

[29] Hutabarat, S dan S. M. Evans. 1995. Pengantar Oceanografi. Universitas Indonesia Press, Jakarta

[31] Winanto.2004. Memproduksi Benih Tiram Mutiara. Penebar Swadaya. Jakarta

[32] Ghufron.M, dan H. Kordi.2005.Budidaya Ikan Laut di Keramba Jaring Apung.Penerbit Rineka Cipta, Jakarta

[33] Sastrawijaya, A. T. 2000. Pencemaran Lingkungan. Penerbit Rineka Cipta, Jakarta.

[34] Anonymous. 1985. Budidaya Rotifera (Brachionus plicatilis OF Muller) Seri Ke Tiga. Proyek Penelitian dan Pengembangan Budidaya Laut. Serang.

[35] Bal and Rao.1984. Marine Fisheries. Tata.Mc.Graw-Hill Publishing Company Limited, New Delhi.

[36] Nontji. 1993.Laut Nusantara. .Jakarta : Penerbit Djambatan.

[37] Nybakken, J. W. 1992. Biologi Laut. PT. Gramedia, Jakarta

\section{Chapters in Books:}

[2] FAO,2010, Aquaculture development.4.Ecosystem approach to aquaculture.FAO.Technical Guidenies for Responsible Fisheries.No. 5, Suppl. 4.Food and Agriculture Organization of the United Nations, Rome, 53 pp.

[24] Keputusan Menteri Negara Lingkungan Hidup. 2004. Baku Mutu Air Laut. Keputusan Meneg. KLH No 51 tahun 2004 , tanggal 8 April 2004, Jakarta

\section{Theses:}

[5] Purnomo. A. 1992. Site Selection for Sustainable Coastal Shrimp Ponds.CentralReseach Institute for Fishery.Agency for Agriculture and DevelopmentMinstry of Agriculture.Jakarta-Bandung.

\section{Proceedings Papers:}

[4] Muir. J. F and J. M. Kapetsky. 1998. Site Selection Decisions and Project Cost.The Case of Brackish Water Pond System. Aquaculrure EngeneeringTechnogies for The Future. IChemE Symposium Series No. 111, EFCEPublication Series No 66, Scotland.

[7] Mustafa,A.,Radiarta.I.N.,Rachmansyah.2011. Profil dan Kesesuaian Lahan Akuakultur Mendukung Minapolitan.Badan Penelitian dan Pengembangan Kelautan dan Perikanan Pusat Penelitian dan Pengembangan Perikanan Budidaya.Jakarta.

[14] Mayunar, R. Purba, P, Imanto,T. 1995. Pemilihan lokasi budidaya ikan laut. Prosiding temu usaha pemasyarakatan teknologi keramba jaring apung bagi budidaya laut, Puslitbang Perikanan. Badan Litbang Pertanian: 179 - 189.

[21] Novotny, V.1994. Proc. Surface Water Quality, Annual Conference, Water Environment Federation, Chicago, Ill. October 1994

[25] Lee, JH.,D.K,F, Arega and b. Qu.2001. Environmental management of mariculture in Hongkong.Technical Report.Departemen of Civil Engineering.The University of Hongkong.

[26] Ahmad,T., P.T.Imanto, Muchari, A .Basyarie, P. Sunyoto, B. Slamet, Mayunar, R.Purba, S.Diana, S.Redjeki, A.S. Pranowo, S.Murtiningsih. 1991. Operasional pembesaran kerapu dalam keramba jaring apung. Laporan Teknis Balai Penelitian Perikanan Budidaya Pantai. Maros.59 hal

[27] Barg, U.C. 1992. Guidelines for The Promotion of Environmental Management of Coastal Aquaculture Development. FAO Fisheries Technical Paper 328. FAO, Rome/ 122pp

[30] Imanto, P.T., N. Lisyanto, B. Priono. 1995. Desain dan konstruksi keramba jaring apung untuk budidaya ikan laut, halaman 171 178 dalam Prosiding temu usaha pemasyarakatan teknologi keramba jaring apung bagi budidaya laut 